\title{
FOUCAULT'S GENEALOGY AS EPISTEMOLOGY ${ }^{1}$
}

\begin{abstract}
In this paper, I argue that Foucault's theorizing about knowledge, power and the subject of knowledge should be part of epistemology as philosophical discipline. Epistemology is redefined and understood as theorizing about knowledge in general and as inseparable from politics. The paper focuses on genealogy as epistemology starting from the thesis that Foucault in his genealogical works develops a conception of power that has important consequences on epistemological concepts of knowledge and the knower/subject of knowledge who is not a constituting Cartesian subject, but a constituted subject, an effect of power and knowledge constellations. Genealogy (as epistemology) is further understood as "insurrection of subjugated knowledges", of knowledges and knowers discredited and marginalized by dominant totalizing theories. Subjugated, local knowledges have the potential of creating new epistemological space, because their relation to power could be different than that of dominant knowledges. Therefore, genealogy could be seen as an epistemological method that opens new possibilities for theorizing about knowledge.
\end{abstract}

Key words: epistemology, genealogy, knowledge, power, subject of knowledge, subjugated knowledges

\section{Introduction}

Michel Foucault was interested in epistemological problems from his earliest writings and he provided probably one of the strongest critiques of the traditional epistemological framework. However, he did not only criticize traditional epistemology, but also offered a new way of looking into the epistemological problems and potentially a new vision of what epistemology could be in the future. In both archaeological and genealogical works, Foucault challenges some of the core epistemological concepts and ideas, arguing against the ahistoric concepts of knowledge and the knower, subject-centered procedures of justification, and totalizing and universalistic pretensions of traditional accounts. This article focuses on Foucault's epistemological account he gave in his so-called genealogical or 'middle' works, primarily because in those works he develops a conception of power that has important consequences on epistemological

1 This paper is realized as a part of the project no. 47021 financed by the Ministry of Education, Science and Technology of the Republic of Serbia. 
concepts of knowledge and the knower/subject of knowledge. His conception of power as productive and creative is crucial for his understanding of the subject of knowledge, who is not any more constituting Cartesian subject, but constituted subject, an effect of power and knowledge constellation. Focus on genealogy as epistemology is inspired further by Foucault's account of genealogy as "insurrection of subjugated knowledges", of knowledges and knowers discredited and marginalized by the dominant totalizing theories. Genealogy is the method which not only focuses its attention to uncover all those marginalized discourses, but calls for their rebellion, resistance against totalizing discourses. Subjugated, local knowledges have the potential, as counter-discourses, of creating new epistemological space, because their relation to power could be different than that of dominant knowledges. Genealogy can be seen as an epistemological method, which opens new possibilities for theorizing about knowledge.

\section{Foucault As an 'Epistemologist'?}

Foucault was interested in questions about knowledge and science from his earliest works. However, his name and ideas are usually not included in discussions about problems within epistemology as a philosophical discipline. Like many other continental thinkers, Foucault is not even considered as a 'philosopher' because, allegedly, he does have "nothing to say" about "philosophical theories of truth and knowledge" (Prado 2000, 2). Richard Rorty tells us that "a distinguished analytic philosopher ... urged that 'intellectual hygiene' requires one not to read ... Foucault" (Rorty 1982, 224). Or, as Linda Alcoff notes, Foucault is "often read as [someone who tries] to deconstruct epistemology by undermining its principal questions and founding premises" (Alcoff 2008, 115). In addition, Hilary Putnam, although he considers Foucault as a "distinguished continental philosopher", argues that in Foucault's philosophy beliefs are "mainly determined by unreason and selfish power" (Putnam 1981, ix, 162). Therefore, it seems that Foucault is outside the language game of epistemology. But, this is not all, because for many continental philosophers, "Foucault represents such a radical rupture with epistemology that we cannot interrogate his own claims about knowledge in terms of traditional epistemological questions without distorting his project" (Alcoff 2008, 116).

It seems that we have here a rare example of a consensus among analytical and continental philosophers, because they mostly agree that Foucault is not an epistemologist. Even Foucault himself would probably agree with both his critics and sympathizers when they say that he does not do epistemology, if 'doing epistemology' means providing a 'theory' of knowledge or offering an account of necessary and sufficient reasons for knowledge (cf. Faubion 1998, xxiv). And, he has a very simple explanation for that: "I'm not an analytical philosopher. Nobody's perfect" (Foucault 1997, 176). Moreover, Foucault himself usually is not very helpful regarding his place within the field of philosophy in general and epistemology in particular. Sometimes, he is even satisfied with the description of his work given by his critics as 'non-philosophical', but in other situations he is more explicit and helpful regarding how himself sees his own position in 
philosophy and epistemology. In an essay he wrote about himself for Dictionnaire des philosophes under the pseudonym Maurice Florence, Foucault explicitly says that "to the extent that Foucault fits into the philosophical tradition, it is the critical tradition of Kant, and his project could be called a Critical History of Thought" (Foucault 1998b, 459). However, Kant, awaken from the dogmatic sleep by Hume, tried to save philosophy and epistemology from skepticism. He introduced the pure forms of knowledge as necessary conditions of all our knowledge, and the Kantian model seeks what in apparently contingent is actually necessary (Gutting 2005). Foucault, on the other side, although part of 'the critical tradition of Kant', inverts his move and asks what in apparently necessary knowledge, that of modern human sciences, might be contingent. He accepts Kantian critical stance, but does not accept his foundationalism and transcendentalism: "Foucault's critique examines claims of necessity with a view to undermine them by showing that they are merely historical contingencies" (ibid., 59).

Foucault's position within the field of philosophy is similar to that of Nietzsche, who is the main influence for Foucault's genealogical works:

Like Nietzsche, Foucault was a writer whose philosophical status was questionable. He was a bit outrageous. He did not produce arguments. ... He was not developing a theory of truth or rationality, but rather analyzing the relations of power and knowledge that underpin certain understandings of truth and rationality. Unlike Nietzsche, he was explicitly political (Sawicki 1991, 5).

Therefore, if someone is looking for theories or arguments in a standard sense in Foucault's work that is precisely what it will not be found there. However, this very fact does not exclude Foucault from the field of theorizing about the epistemological problems such as knowledge, subjectivity or rationality, nor it makes his work irrelevant for epistemological studies. What needs to be accepted is that Foucault thinks, writes and argues about these problems in a different way that is not unintelligible for epistemologists, and more importantly, Foucault's work provide probably one of the most direct and clearest critiques of Cartesian and Kantian legacy in epistemology.

In order to understand Foucault as an epistemologist, we need to redefine the term "epistemology". Epistemology should not be understood as a "foundationalist, anti-skeptical project. ... [E]pistemology [should be understood] as the theorizing about knowledge" (Alcoff 2008, 4) in general. On the other side, and for this paper even more important, epistemology should be seen as inseparable from politics. There are not epistemological inquiries that are not at the same time political, and precisely that is the claim made by Foucault. Foucault is not an epistemologist in traditional sense, but he is epistemologist in a sense that he theorizes about epistemological problems and argues that epistemology and politics, knowledge and power, are connected and that that connection should be explored.

In Foucault's writings, both in 'archaeological' and 'genealogical' periods, many core notions of traditional epistemology, are challenged. Knowledge is not attributed to beliefs and/or sets of beliefs, and it is not the sum of justified true beliefs. Knowledge includes much more than that: the space where the subject 
stands as knower, and the field in which concepts are determined and statements are arranged (cf. Alcoff 2008, 144). He is against the conception of knowledge as a possession of truth, and of the conception of the self as the unitary condition of cognition. He is also against the conception of the truth as an ultimate value, as evident to reasoned inquiry and as objective.

It is difficult and probably wrong to try to give a holistic account of epistemological problems in Foucault's writings because his work resists every attempt to be put in something unitary and totalizing, and also because he changed his views about a number of things in his work over the years including his views about epistemological problems.

At first, it seems that his works during the 1960s are the best candidates for an epistemological inquiry, and it is not surprising that when analytical philosophers and epistemologists read Foucault at all, they usually read his 'archaeological' books, ${ }^{2}$ and argue that he does not have epistemology (cf. Rorty 1986). During the 'archaeological' period, Foucault was interested in an epistemic context in which some bodies of knowledge became intelligible and authoritative in the field of human sciences as systems of knowledge. Archaeology tries to discover the rules of formation that dictate what elements and structures a discourse ${ }^{3}$ must possess in order to be admitted in the field of knowledge during the certain historical period. Archaeology is a very detailed, descriptive and value-neutral inquiry onto disciplines, expert idioms and systems of knowledge and truth. ${ }^{4}$ Archaeology is the description of systems of thought, with no attempt to explain changes from one system to another.

Although Dreyfus and Rabinow are probably right when they say that " $[t]$ here is no pre- and post-archaeology or genealogy in Foucault" (Dreyfus and Rabinow 1982, 104), there are at least two important reasons why it is better to grasp Foucault's critique of traditional epistemology in genealogical and not in archaeological works. After the events in May 1968, Foucault started to think more about the concept of power, which became the central concept of his genealogical works, and second, he at least in one essay described genealogy as an 'insurrection of subjugated knowledges' and subjugated knowers, marginalized knowledges and knowers that could be seen as resistance against totalizing and dominant knowledges which eliminate others through violence. Despite the fact that "Foucault himself claims although he does not appear, in the archaeological texts, to be analyzing power, in retrospect, he sees all of his work contributing to outlining the intricate and highly variable forms of power in discursive and non-discursive practices" (Grosz 1990, 81), the concept of power, and even the term 'power' is rarely used by Foucault in his early writings, and in one of

2 Putnam, for example, claims that The Birth of the Clinic is "perhaps Foucault's best book" (Putnam 1981, 155).

3 'Discourse' is Foucault's technical term that denotes an actually exiting group of statements that belong to the same discursive formation, which means the same historically situated field of knowledge.

4 Cf. Foucault 1972; Dreyfus and Rabinow 1982, part I; May 1993, ch.2; Rouse 1994; Prado 2000, ch.2; Alcoff 2008, ch. 4; Kelly 2008, ch.1. 
his early books, namely Madness and Civilization, he uses power in a different meaning than he does in genealogical works - as silencing, repressive and forbidding power. Without intending to argue against Foucault's retrospective 'insight' into his work during the 1960s, I will focus primarily, and based on two reasons provided above, on his genealogical method and work, where he explicitly develops an account of power which has very important epistemological consequences.

If we speak about knowledge, Foucault during the genealogical period never uses as examples of knowledge simple common-sense beliefs or perceptions - for example, "Grass is green" - or some beliefs from natural sciences that are usual among traditional epistemologists. His examples come from 'suspicious' sciences, human and social sciences, sciences with low epistemic status, so the starting points for Foucault's 'epistemological' inquiries are not common accepted beliefs, but the most controversial and complicated beliefs from the sciences of man. This makes his account of epistemological problems even more powerful because, "[i]t has the advantage of being closer to actual practices of knowledge production, and [it] contributes toward inchoate understanding of the complex relationships which in fact exist between knowledge, power and subjectivity" (Alcoff 2008, 141).

Foucault is primarily interested in understanding the production of knowledges and truths, in the plural, in their historical specificities. He wants to know how and why we think some things are true, and how and why we take some things as knowledge, and these questions make Foucault's genealogical project not only different from what we are used to see in epistemological accounts, but also relevant for us today. His histories/genealogies are not meant to stay in history, and they are not histories for their own sake. They are histories of the present, with an aim to show how our knowledge standards have evolved, to explain their contingencies and to show that there is nothing necessary or inevitable in our dogmatic attachments with the current regimes of truth and knowledge. Foucault criticizes the traditional epistemological paradigm so strong, that we can only compare his critique with that one provided by the philosophers of modern and the Enlightenment era against the Scholastic dogmatism and authoritarianism (ibid., 149).

\section{Genealogical Method}

The method called 'genealogy' Foucault used during the period between 1971 and 1976. The term 'genealogy' Foucault takes from Nietzsche, and although he usually rejects all labels, he was quite satisfied with the description of his work as 'Nietzschean' and it can be said that his 'epistemology' developed during this period is Nietzschean as well.

Genealogy is "the history of the present" (Foucault 1995, 31), which means that it begins with a diagnosis of the current situation, that it is a history that starts from the present day as diagnosis and as an intervention as well. Genealogy examines the emergence and development of the present rules, practices and 
institutions that claim authority over us. The primary target of genealogy is not the past for its own sake, but to understand and evaluate the present, to make the past no longer present, to leave the past to the past, and to force us to live in the present. "It is only in the present that one can make changes. In order to be free, one needs to continually expose what remains alive of the past in the present and relegate it to the past. To be unaware of the past is to be trapped by it" (O'Farrell 2005, 75). For Foucault, genealogy presents "a transformation of history into totally different form of time" (Foucault 1998a, 385); it "shortens its vision to those things nearest to it" (ibid., 380).

Foucault and Nietzsche share an idea of genealogy as a critique - genealogy is a critique of the efforts to support established authorities on the basis of their origin (Ursprung). Traditional history is a project devoted to seeking for 'origins' of things, discourses, and practices. According to Foucault, this search for origin tries to capture the exact essence of things, because it assumes the existence of immobile forms that precede the external world of accidents and succession. This search assumes and is directed to that which is already there. Contrary to traditional history, genealogy is an 'effective history', which means history that does not unify, but "distinguishes, separates, and disperses" (ibid., 380); a history that is opposed to the search for origins, or ahistorical foundations, metaphysical essences and unchangeable truth. Genealogy is a history without constants, because contrary to the Cartesian tradition, it assumes that nothing in 'man' is sufficiently stable enough to serve as a basis for self-recognition or for understanding others or the world. For genealogist, there are no fixed essences, no underlying unchangeable laws. Genealogy reveals "the secret that [things] have no essences, or that their essence is fabricated" (ibid., 371). Where others (i.e. traditional historians) see continuities, origins and depth, the genealogist sees discontinuities, surfaces of events, small details and minor shifts. The genealogist writes the effective history that is opposed to a suprahistorical perspective that tries to totalize history and to make us comfortable with our past, which in turn offers and assurance of an end toward which the history moves. Genealogy is seen by Foucault as "curative science" (ibid., 382), science that will help us to stop looking for origins, for ultimate truth, for essences behind things that would give them a proper and definite meaning once and for all time. For genealogist, everything is in historical motion and in the process of change.

In genealogical works, Foucault, under the influence of Nietzshe, insists on the connection between power and knowledge. Foucault shares Nietzsche's insight that knowledge is not outside of struggle and conflict; it is not at the safe distance from struggle from which it can pronounce the truth of the conflict. There is no 'outside' of history, there is no neutral point form which is possible to observe and proclaim the truth of various knowledge claims. Knowledge for both Nietzsche and Foucault is not disinterested and objective observation but a weapon: "knowledge is not made for understanding; it is made for cutting" (ibid., 380).

The changes in knowledge are not themselves the result and product of thought itself. When knowledge changes the causes are the social forces that control behavior of individuals. Although Foucault does not reduce knowledge to 
power, he is explicit that knowing is not the process that can achieve a total escape from power relations, and that power has not only constraining role, and does not operate only by eliminating some knowledge; it also has a positive epistemic role in producing knowledges, subjects and objects of knowledges and truths.

Throughout Foucault's genealogical period, he was influenced by Nietzsche's idea of looking for power behind accepted and dominant knowledges, sciences, religions and other authorities, which usually present themselves as grounded in disinterested evidence and argument. For a genealogist, "everything is potentially enmeshed in the networks of power which ... are increasingly concerned with the advance of knowledge. We are now at the verge of sacrificing ourselves to our own deepest lie: our belief that knowledge exists separately from power" (Dreyfus and Rabinow 1982, 114).

\section{Power}

The key concept in Foucault's genealogical works is the concept of power. He does not provide a 'theory' of power, or a 'theory' of knowledge. He usually speaks about what power is not, rather than providing a positive account of it. In that way, Foucault tries to show how his ideas on power differ from other proposed accounts, especially those given by liberal theorists and Marxists.

Foucault distances himself from liberal and Marxist accounts of power. Both liberals and Marxists operate with a so-called "juridico-discursive" (Foucault 1990,82 ) model of power that assumes that power is possessed (by pre-social individual, or by class, or by people, etc.); that power is centralized (in a law, or in economy, or in the state, etc.); and that power is primarily repressive. According to 'juridico-discursive' model of power, power is essentially negative - it produces nothing but "limit and lack" (ibid., 83). Power is everywhere the same - it operates by endlessly reproduced mechanisms of law and censorship. Power is, finally, domination - all it can do is to forbid and command the obedience.

For the liberal tradition, the site of power is the state, which through laws and social practices they involve institutionalizes what is acceptable and unacceptable within the certain community/state. Law appears as a mechanism of power as prohibition. For Marxists, power is the exercise of repression by the state, an ability of the ruling class to ensure the exploitation of surplus value of the production's process that the capitalists keep for themselves. Although liberals and Marxists do not have the same or even similar political and economic goals, they both consider power as negative and restrictive upon the subjects. Precisely because power is negative and restrictive, it leaves space for potentially disobedient subjectivity, and that is the reason why the state and its power manifested through laws is important for both, liberals and Marxists. ${ }^{5}$ After the events in 1968, Foucault started explicitly to challenge this conception of power as negative and prohibitive, and to consider that account as too narrow and one-dimensional. In the interview he gave in 1977,

5 For a more detailed account of liberal and Marxists' conceptions of power, cf. Foucault 1980b, 109-133; see May 1993, 35-38 for differences between liberals, Marxists and Foucault. 
published under the title "Truth and Power", Foucault explains the problem he sees in negative conception of power:

[I]t seems to me now that the notion of repression is quite inadequate for capturing what is precisely the productive aspect of power. In defining the effects of power as repression, one adopts a purely juridical conception of such power, one identifies power with a law which says no, power is taken above all as carrying the force of prohibition. Now I believe that this is a wholly negative, narrow, skeletal conception of power, one which has been curiously widespread. If power were never anything but repressive, if it never did anything but to say no, do you really think one would be brought to obey it? What makes power hold good, what makes it accepted, is simply the fact that it doesn't only weigh on us a force that says no, but it traverses and produces things, it induces pleasure, forms knowledge, produces discourse. It needs to be considered as a productive network which runs through the whole social body, much more than as a negative instance whose function is repression (Foucault 1980b, 119).

Foucault does not deny the 'negative' side of power, but believes that it is precisely that - one side, and therefore not a complete picture: we cannot understand power fully and completely if we understand it as negative and as it only says 'no'.

Negative conceptions of power have direct implications for how some important epistemological questions are understood. For example, the Cartesian legacy and liberal conception of power as negative result in very specific conceptions of knowledge and a knower in Western epistemology. Traditional epistemology does not accept knowledge as a political event. If something is true knowledge, it has to be dissociated from power; it can appear only in isolated, free space of (meditating) subjectivity. This is the reason why Foucault in "Prison Talk" says that it is generally accepted that "[p]ower makes men mad, and those who govern are blind; only those who keep their distance from power, who are in no way implicated in tyranny, shut up in their Cartesian poêle, their room, their meditations, only those can discover truth" (Foucault 1980a, 51).

Unlike liberals, Marxists do think that knowledge is political, and they even distinguish two sorts of knowledge. First one is 'scientific' and 'true' knowledge that is in accordance with dialectical understanding of history. The second is ideology, or distorted knowledge that is useless except for the ruling class, and therefore false. However, Marxists identify truth with liberation and falsity (ideology) with subjection, which means that both liberals and Marxists believe in one, objective, pure truth and do not approve a political critique of it (cf. May 1993, 38).

The genealogical period in Foucault's work brings new conception of power and subsequently new conception of knowledge. He explicitly rejects analyzing power within the paradigm of repression, because it cannot embrace all aspects of power: power is not only negative, but primarily creative. Power is not only prohibitive, rule-based and uniform, but first and foremost positive and productive; it is everywhere, omnipresent, dispersed all over the social body. As such, power produces and creates the knowing subjects. The relational nature of power depends on a multiplicity of points of resistance: if there is a relation of power, there is a possibility of resistance, which means for Foucault that we are never trapped by 
power - it is always possible to modify its hold. On the other hand, Foucault in his later writings also emphasizes that power relations can be implemented only where there is a possibility of resistance, which means in cases where there is a struggle, a conflict, a dynamical relationship between different actions with the possibility of different outcomes. There are no power relationships where there is no possibility of resistance and modification of current temporary alignments of local forms of power. Genealogy, to sum up, sees power as productive and creative network of relations of forces that produces and shapes knowledges and objects of knowledge, and that utilize the effects of knowledges.

\section{The Concepts of Knowledge and the Subject of Knowledge}

By the beginning of the 1970s, Foucault adopted Nietzsche's view that knowledge itself is a product of struggles for power and domination. Although he rarely speaks about the concept of knowledge generally and about its general role in genealogical works, I argue a little bit contra Foucault, that in the first 'methodological' lecture of the series he gave in May 1973 in Brazil, published under the title "Truth and Juridical Forms", his aim is precisely to explain on a more general level the concepts of knowledge and the subject of knowledge, but at the same time as different than they are conceived in traditional epistemology:

Two or three centuries ago, Western philosophy postulated, explicitly or implicitly, the subject as the foundation, as the central core of all knowledge, as that in which and on the basis of which freedom revealed itself and truth could blossom. ... [I]n the field of what we may call the 'theory of knowledge', or in that of epistemology, ... it seems to me that the theory of the subject has remained very philosophical, very Cartesian and Kantian (Foucault 2000, 3).

So, today when someone tries to do the history of, for example, knowledge, he or she "sticks to this subject of knowledge, to the subject of representation as the point of origin from which knowledge is possible and truth appears" (ibid.).

Foucault's project is to do something completely different. Using his genealogical method, he wants to see how a subject come to be constituted that is not definitively given, how the subject constitutes itself within, not outside history and how subject is constantly established and reestablished by history as different and variable. In order to do that, he needs to do something else first: to investigate the concept of knowledge.

Foucault finds the source for the new reconception of knowledge in one of Nietzsche's early essays, "On Truth and the Lie in an Extra-moral Sense". At the very beginning of the essay Nietzsche says that knowledge is an invention of clever animals (Nietzsche 1976). Invention is on the one side a break, but on the other it is something with a small beginning - low, mean, and Foucault wants to counterpose these small and low beginnings of fabrications to the solemnity of origins. 
To say that [knowledge] was invented is to say that it has no origin. More precisely, it is to say, however paradoxical this may be, that knowledge is absolutely not inscribed in human nature. Knowledge doesn't constitute man's oldest instinct; and, conversely, in human behavior, ... the human instinct, there is no such thing as a seed of knowledge (Foucalt 2000, 7-8).

At this point, Foucault detaches himself from philosophical tradition in a very radical way. First, he does not start his reflections about knowledge with, for example, the opening lines of Aristotle's Metaphysics: "ALL men by nature desire to know" (Aristotle 2005, 7). Instead, Foucault quotes the opening lines of an essay written by a 'suspicious' figure in the history of philosophy, Nietzsche, and claims, contrary to the whole tradition starting with Plato and Aristotle, that knowledge "is absolutely not inscribed in human nature".

Knowledge has connections with instincts, but it cannot be present in them, and it is not one instinct among the others. Knowledge has a basis in instincts, but the basis is the confrontation, struggle, between instincts. Knowledge arises as an outcome of a combat, and it is "not instinctive, it is counterinstinctive; just as it is not natural, but counternatural" (Foucault 2000, 7-8). And this is the first sense in which Foucault speaks about knowledge as an 'invention', and not as something that is derived from human nature.

There is a second meaning of 'knowledge as an invention'. Namely, knowledge "isn't even closely connected to the world to be known" (ibid.). In other words, the novelty of knowledge means that knowledge is not just an expression of our experience of things in the world. There is no resemblance or prior affinity between knowledge and things to be known. Therefore, Foucault claims: "In ... strictly Kantian terms, one should say the conditions of experience and the conditions of the object of experience are completely heterogeneous" (ibid., 9).

Knowledge is an attempt to impose the order in a chaotic world. It is not only the attempt to describe things in the world, because knowledge is not a description (Kelly 2008, 19). "Knowledge can only be a violation of the things to be known, and not a perception, a recognition, an identification of or with those things" (Foucault 2000, 9). What knowledge does is imposing on things in the world "an order which is new" (Kelly 2008, 20), and the relation between knowledge and things to be known is never merely representational, because there is no relation of continuity between knowledge and things to be known, but the relations of power and struggle, which mean that we do not have to postulate (like Descartes had to) the existence of God, who traditionally has guaranteed the continuity and harmony between knowledge and the things in the world. However, if there is not relation of continuity between knowledge and the instincts, but only discontinuity and power relations, "then it's not God that disappears, but subject in its unity and sovereignty" (Foucault 2000, 10). If the mechanisms of instincts are on a completely different level than knowledge is, we do not need to postulate the unity of human subject that has been traditionally given beforehand and definitively.

Foucault follows Nietzsche who argues that there is no nature of knowledge, no essence of knowledge and of the universal conditions of knowledge. 
$[\mathrm{K}]$ nowledge is always the historical and circumstantial result of conditions outside the domain of knowledge. In reality knowledge is an event that falls under the category of activity. Knowledge is not a faculty or a universal structure. ... [K] nowledge ... only belongs to the order of results, events, effects (ibid., 13-14).

This Nietzschean view of knowledge as a product, result and effect of struggles for power that Foucault adopts has important consequences for the understanding of the 'subject' of knowledge. Foucault does not understand subject as universal, timeless or abstract and, which is at the source of how one makes sense of the world, and which is the foundation of all knowledge, thought and action. For Foucault, the subject of knowledge/knower traditional epistemology speaks about does not exist in his/her autonomy and universality. Foucault explicitly rejects the subject of the Enlightenment understood as an $a$ priori subject of knowledge: "What I refused was precisely that you first of all set up a theory of the subject. ... What I wanted to know was how the subject constituted himself in such and such determinate form" (Foucault quoted in McLaren 1997, 112). The subject is an effect, the product of specific power and knowledge constellation. That subject is not prior the history, and not pregiven. It is created and changed by outside events; it is constantly dissolved and recreated in different configurations along with other forms of knowledge and social practices (cf. O'Farrell 2005, 110-113). This conception of the subject of knowledge as an effect of power and knowledge constellations, or this dismissal of the traditional knower as one of the central epistemological categories is probably the most radical Foucault's epistemological move in his genealogical works. To put it simply, epistemology is not based on the concept of the knower, and knowledge does not have a cause in independently existing knower opposite to the world and other knowers. Foucault rejects the constituting knowing subject of the Enlightenment epistemology. This rejection, however, worries some philosophers, who argue that we need the notion of that subject in order to have political and moral agency (cf. McLaren 1997, 110). Alcoff, for example, worries that, according to Foucault, we, as subjects, are overdetermined, constructed by power/knowledge relations, social discourse and cultural practice (Alcoff 1988, 416). Foucault's subject is, therefore, "totally determined, because it is enmeshed in relationships of power and is produced as effect through disciplines and practices" (McLaren 1997, 110), and unable to resist.

However, Foucault does not reject or abandon the subject completely but he does reject the 'philosophy of the subject', the One, universal, disembodied subject, out of space and time, and outside power relations. Foucault's conception of the subject of knowledge displaces the traditional dichotomy between the constituting Cartesian subject, who possesses agency and autonomy, and constituted subject that is wholly determined by social forces. For Foucault, the subject is constituted but it is at the same time an agonism, a permanent provocation to power/knowledge constellation that defines its subjectivity (cf. Hekman 1990, 72-73). Only within the Enlightenment framework that is based on dualisms, such as subject/object, rational/irrational, etc., the constituted subject is passive and without agency. In Foucault's work, where the dualist thinking is rejected, the constituted subject is the subject who acts and resists. 
In other words, it can be argued that Foucauldian approach to the subject of knowledge rejects the epistemology that rests on traditional dualisms, and therefore, could escape objections regarding the possibility of action in the domain of the political and the possibility of knowledge in the domain of epistemology.

\section{Knowledge As Resistance: Genealogy As an Insurrection of Subjugated Knowledges}

Although Foucault 'defines' power as depending on resistance, and although he claims that power always implies resistance, resistance is the concept that is underdeveloped in Foucault's work (McLaren 1997, 123). In the lecture Foucault gave in 1976, he explicitly speaks about 'subjugated knowledges' and their potential to be forms of resistance to dominant knowledge/knowledges, and about genealogy as a method of resistance.

Although Foucault in many of his interviews tries to clarify his view on the concept of resistance, I want to argue that the first lecture in the series of Society Must Be Defended is very important, because there we can see in the most precise way how knowledge/knowledges can be seen as tools of resistance.

A genealogy of knowledges explains the struggle of one knowledge or episteme ${ }^{6}$ against other knowledges or epistemes. The epistemologically important thing here is that what we currently call 'knowledge' is actually one knowledge, the dominant one, the knowledge that in a struggle defeated other knowledges. On the other hand, genealogy as a method is designed to facilitate "the insurrection of subjugated knowledges" (Foucault 2003, 7). Under the term 'subjugated knowledges', Foucault means two things. First, the term refers to "blocks of historical knowledges that were present in the functional and scientific ensembles, but which were masked" (ibid.). The genealogist, then, reactivates them and reveals their existence. Second, and more importantly, the term refers to

a whole series of knowledges, as insufficiently elaborated knowledges: naïve knowledges, inferior knowledges, knowledges that are below the required level of erudition or scientificity. ... [T] he knowledge of ... the patient, the nurse, the doctor, that is parallel to, marginal to, medical knowledge, the knowledge of the delinquent, ... [knowledge of] what people know (and this is by no means the same thing as common knowledge or common sense but, on the contrary, a particular knowledge, a knowledge that is local, regional, or differential,

6 Episteme is a technical term Foucault introduced in his archaeological works. He explains in one of his interviews:

I would like to define episteme ... as the strategic apparatus which permits of separating out from among all the statements which are possible those that will be acceptable within, I won't say a scientific theory, but a field of scientificity, and which it is possible to say are true or false. The episteme is the 'apparatus' which makes possible the separation, not of the true from false, but of what may from what may not be characterized as scientific (Foucault 1980c, 197).

It could be argued that, to the some extent, episteme is similar to Kuhnian paradigm. 
incapable of unanimity and which derives its power solely from the fact that it is different from all knowledges that surround it), ... at a local level, ... disqualified knowledges (ibid., 7-8).

Therefore, genealogy uses history to give a voice to the marginal and submerged knowledges that are 'a little beneath history'. Foucault wants to show that some paths in the history were not taken and that are a number of unactualized possibilities and events that do not fit the dominant functionalist schema of knowledge in sciences of man.

Genealogy is about the insurrection or rebellion of knowledges not against the scientific methods, concepts or content, but against "the centralizing powereffects that are bound up with the institutionalization and workings of any scientific discourse organized in a society such as ours" (ibid., 9). ${ }^{7}$ This means that when something is claimed to be a 'science' or something has an aspiration to be a 'science, Foucault in that claim or aspiration does not see the rational structure of that potential 'science', or that its propositions are rationally verified. On the contrary, he sees in that kind of claim or aspiration an attempt to disqualify some other knowledges, and to attach itself to scientific discourse (ibid., 10).

Genealogy, as a method, is therefore, an attempt to desubjugate historical knowledges, to set them free, or in other words, to enable them to oppose and struggle against the coercion of a unitary, formal, and scientific theoretical discourse. The project of these disorderly and tattered genealogies is to reactivate local knowledges ... against the scientific hierarchicalization of knowledge and its intrinsic power-effects (ibid.).

Why is Foucault's idea of genealogy as the insurrection of subjugated, oppressed and local knowledges epistemologically relevant? First of all, Foucault's account of knowledges in the plural, dissociates the concept of knowledge from the concept of truth. Traditionally speaking, knowledge cannot be knowledge if it is not true; there cannot be a false knowledge. And the traditional belief that "We all agree that what we know is true", in Foucault's account of knowledges in the plural, of struggle between knowledges, and one's 'winning,' now dominant knowledge over the number of different and local knowledges, gains a completely new meaning. What 'we all' allegedly agree in our societies is that the one, dominant knowledge, or that we call 'science', is 'true', and that other oppressed, subjugated, local and naïve knowledges are 'false'. They are false, not because they are 'irrational' or not in accordance with some 'objective' methods of inquiry. They are false because they cannot fit into the mold of dominant scientific and epistemological discourse. Consequently, some of them in some other constellation of power relations could be true, and can subvert or undermine the supremacy of dominant knowledge(s). But, this is still not enough for a radical critique. Namely, what Foucault sees in dominant, totalizing knowledges is that they can work or operate only if they exercise some kind of coercion and violence against local and particular knowledges, because they

By 'society such as ours' Foucault always thinks of the Western societies. 
need to subsume them under their universal and totalizing structures (cf. Alcoff 2008, 154). Linda Alcoff sees Foucault's account of subjugated knowledges as important because they are, according to her,

valorized not because they represent more accurate representation of the Real as it exists in itself, ... but because they do not require the amount of violence, distortion, and omission that global knowledges require. ... [In other words], they have a different relationship to power, and ... this different relationship will constitute a different field [of knowledge] (ibid., 155).

The structure or the form of subjugated and local knowledges is different, because they have a different position in relation to dominant systems of power. They are not local or subjugated because they have not reached domination yet, but because "they do not aspire to dominance. They do not construct competing unitary, formal, totalizing theoretical systems" (ibid., 156). Linda Alcoff, in her account of Foucault's idea of 'subjugated knowledges' argues that the important distinction that should be made here is not that one between dominant and subjugated knowledges, which Foucault actually makes, but that one between local and 'hegemony-seeking'8 knowledges, because the second distinction allows us to mark important differences that exist between so-called 'subjugated knowledges', and to open the possibility to think about epistemology in a new, productive, innovative ways (ibid., 157).

First, although it can be argued that there is a large number of subjugated knowledges, including knowledges of, for example, Neo-Nazis groups, there is a criterion Foucault could use and according to which knowledges of those groups cannot be considered as a place for critical intervention. The main question/ criterion is whether those kinds of 'knowledges' seek for disqualification and marginalization of other knowledges. In the case of Neo-Nazis groups, it is more than obvious that their knowledge seeks for domination, and requires, even includes the exercise of violence against the other knowledges and their disqualification.

The second question that should be addressed is: How Foucault can be sure that his critique does not lead toward the mere turning of the subjugated knowledge into the dominant position? Although Foucault would probably answer that we can never be sure and that we cannot predict the future, again, the distinction between local and 'hegemony'-seeking knowledges could help: the mere reversal of knowledges will happen only in the case when the subjugated knowledge is a 'hegemony'-seeking one. In the case when subjugated knowledge is not 'hegemony'-seeking, there is a possibility of a new relation between knowledge and power, and for a new, different kind of knowledge than the one represented in 'science' or in dominant knowledge in our societies.

The important consequence of Foucault's account of subjugated knowledges in the first lecture in Society Must Be Defended, is that knowledges, subjugated, local knowledges could be a form of a resistance to dominant knowledges and discourses. Precisely because subjugated knowledges are local and spatially/

In this distinction, Alcoff uses the Marxist term 'hegemony', which Foucault himself never used. 
temporally situated, and precisely because they are different from the dominant ones, they are also 'innovative' and 'creative', and they can be a form of a resistance. ${ }^{9}$

Through the account of subjugated or local knowledges, Foucault actually gives us the possibility to imagine a different kind of epistemology not as a solution for our current epistemological issues and theories that can replace or overturn the dominant paradigm as a better or more correct way of theorizing about and describing the world. Namely, what Foucault's general epistemological reflections show is that we should focus on specific, local and particular, because we cannot escape, despite all the efforts, our temporal, cultural, political, and local specificity and particularity. This leads some theorists, such as Linda Alcoff to claim that " $[t]$ he specificity and locatedness of epistemology ... is perhaps the most important distinction to be made between [Foucault's] conception of epistemology and traditional accounts" (ibid.,160).

Genealogical method, therefore, I argue, can be seen as epistemological, and it helps us in detaching ourselves from dogmatic transcendent epistemological formulations and creates the possibility for us to imagine a new, different epistemological project. "Providing [the genealogies] of present day 'absolute' truths will have a liberating effect, dislodging their power and thus freeing us to imagine new possibilities" (ibid., 119).

To sum up, Foucault in his genealogical period, under Nietzsche's influence, develops a critique of traditional epistemology and its core concepts of knowledge and subject of knowledge imagined as dissociated from everything political, local, social and culturally specific. He argues in favor of marginalized voices and knowledges, because he sees them as potential sources of resistance against dominant, totalizing knowledges that deny their situatedness and historical specificity, proclaiming themselves for absolute and universal truths.

\section{Conclusion}

Foucault's genealogical method seen as epistemological has shown that genealogy is a radical critique of knowledge, science and truth as they appear within the traditional epistemological framework. I have argued that Foucault's genealogy should be seen as one of the biggest challenges to our uncritical commitments to allegedly neutral, objective and ahistorical reasoning. Foucault, following Nietzsche, breaks with the traditional assumption of the subject as a foundation of knowledge, of knowledge as disinterested and apolitical event, and as something that should be kept on the safe distance from power. Because power in Foucault's account is primarily productive and creative, Foucault provides a completely different understanding of knowledge and of so-called subject of knowledge, than they are traditionally understood. For Foucault, knowledge is always situated, local and contextual. Knowledge is an event, effect, not a faculty 
or universal structure. The subject/knower is not unchangeable or abstract; it is always produced and reproduced, established and reestablished in its very form through history. Foucault provides an 'epistemology' without the subject/ knower in traditional sense, and this move is the most radical moment in his epistemological work.

Foucault's contribution to epistemology in general consists precisely in his insistence that our theories should be focused on the specific, the local and the particular. Our theories, including epistemological ones, are not meant to stay with us forever; they are changeable, dynamic and temporary, and we should use them as tools in specific situations that we see as the moments for intervention and attack. On the other hand, genealogy as a critical method could help us to see potential dangers in our theoretical commitments and attachments. What Foucault has realized is that we cannot get out of power relations, and that there is no 'innocent' position from which we can be sure that what we are doing is right and our theories purely 'liberatory'. Genealogical critique reminds us on the possible dangers of our accounts and prevents us to become too comfortable with our own positions and 'truths'.

\section{References}

Alcoff, Linda. 1988. "Cultural Feminism Versus Post-Structuralism: The Identity Crisis in Feminist Theory." Signs 13(3): 405-436.

Alcoff, Linda. 2008. Real Knowing: New Versions of the Coherence Theory. Ithaca and London: Cornell University Press.

Aristotle. 2005. Metaphysics. NuVision Publication.

Dreyfus, Hubert L., Paul Rabinow. 1982. Michel Foucault: Beyond Structuralism and Hermeneutics. Harvester Wheatsheaf.

Faubion, James. D. 1998. “Introduction.” In Essential Works of Foucault 19541984, Volume Two: Aesthetics, Method, and Epistemology, ed. James D. Faubion, xiii-xliii. New York: The New Press.

Foucault, Michel. 1972. The Archaeology of Knowledge and The Discourse on Language. New York: Harper \& Row.

Foucault, Michel. 1980a. "Prison Talk." In Power/Knowledge: Selected Interviews and Other Writings 1972-1977, ed. Colin Gordon, 37-54. The Harvester Press.

Foucault, Michel. 1980b. "Truth and Power." In Power/Knowledge: Selected Interviews and Other Writings 1972-1977, ed. Colin Gordon, 109-133.The Harvester Press.

Foucault, Michel. 1980c. “The Confessions of the Flesh." In Power/Knowledge: Selected Interviews and Other Writings 1972-1977, ed. Colin Gordon, 194228. The Harvester Press.

Foucault, Michel. 1990. The History of Sexuality: Volume One, An Introduction. New York: Vintage Books. 
Foucault, Michel. 1995. Discipline and Punish: The Birth of the Prison. New York: Vintage Books.

Foucault, M. 1997. "Sexuality and Solitude." In Essential Works of Foucault 19541984, Volume One: Ethics, ed. Paul Rabinow, 175-184. New York: The New Press.

Foucault, M. 1998a. "Nietzsche, Genealogy, History." In Essential Works of Foucault 1954-1984, Volume Two: Aesthetics, Method, and Epistemology, ed. James D. Faubion, 369-391. New York: The New Press.

Foucault, Michel. [Maurice Florence].1998b. "Foucault." In Essential Works of Foucault 1954-1984, Volume Two: Aesthetics, Method, and Epistemology, ed. James D. Faubion, 459-463. New York: The New Press.

Foucault, Michel. 2000. "Truth and Juridical Forms." In Essential Works of Foucault 1954-1984, Volume Three: Power, ed. James D. Faubion, 1-89. New York: The New Press.

Foucault, Michel. 2003. Society Must Be Defended: Lectures at the College de France 1975-1976. London: Penguin.

Grosz, Elizabeth. 1990. "Contemporary Theories of Power and Subjectivity." In Feminist Knowledge: Critique and Construct, ed. Sneja Gunew, 59-128. London: Routledge.

Gutting, Gary. 2005. Foucault: A Very Short Introduction. New York: Oxford University Press.

Hekman, Susan. 1990. Gender and Knowledge: Elements of a Postmodern Feminism, Cambridge: Polity Press.

Kelly, Michael. 2008. The Political Philosophy of Michel Foucault. New York, London: Routledge.

May, Todd. 1993. Between Genealogy and Epistemology: Psychology, Politics and Knowledge in the Thought of Michel Foucault. University Park, Pennsylvania: The Pennsylvania University Press.

McLaren, Margaret. 1997. "Foucault and the Subject of Feminism." Social Theory and Practice 23(1): 109-127.

Nietzsche, Friedrich. 1976. The Portable Nietzsche. New York: Penguin.

O'Farrell, Clare. 2005. Michel Foucault. London: Sage Publications.

Prado, C.G. 2000. Starting With Foucault: An Introduction to Genealogy. Westview Press.

Putnam, Hilary. 1981. Reason, Truth and History. Cambridge: Cambridge University Press.

Rorty, Richard. 1982. Consequences of Pragmatism. Minneapolis: University of Minnesota Press.

Rorty, Richard. 1986. "Foucault and Epistemology" In Foucault: A Critical Reader, ed. David Couzens Hoy, 41-50. Oxford: Basil Blackwell.

Rouse, Joseph. 1994. "Power/Knowledge." In The Cambridge Companion to Foucault, ed. Gary Gutting, 92-114. Cambridge: Cambridge University Press.

Sawicki, Jana. 1991. Disciplining Foucault: Feminism, Power and the Body. New York: Routledge. 